\title{
Foraminiferal biostratigraphy and paleoenvironments of the middle Eocene deposits from the northern part of the Tarcău Nappe (Eastern Carpathians, Romania)
}

\author{
Raluca BINDIU* and Sorin FILIPESCU \\ Babeş-Bolyai University, Department of Geology, Kogălniceanu 1, 400084 Cluj-Napoca, Romania
}

Received: April 2015; accepted August 2015

Available online 13 August 2015

DOI: http://dx.doi.org/10.5038/1937-8602.59.1.4

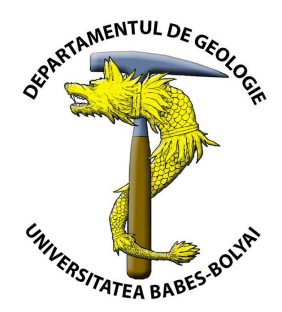

\begin{abstract}
Middle Eocene foraminiferal assemblages have been analyzed from three representative sections of bathyal deposits cropping out along the Brodina Valley and Voroneţ Valley in the northern part of the Tarcău Nappe (Eastern Carpathians, Romania). The foraminiferal assemblages are dominated by coarsely agglutinated taxa characteristic of the "flysch - type" foraminiferal biofacies. The depositional setting was probably upper to middle bathyal, as suggested by the abundance of the tubular forms. The morphogroup analyses showed variations in tubular and infaunal morphotypes, suggesting fluctuations in the organic matter input, oxygenation, and disturbing bottom water currents. Based on the presence of Ammodiscus latus, Reticulophragmium amplectens, Haplophragmoides parvulus, Spirosigmoilinela compressa, Psamminopelta gradsteini and the high abundances of Reophax pilulifer, the studied deposits can be assigned to the upper part of the middle Eocene.
\end{abstract}

Keywords: agglutinated foraminifera, biostratigraphy, palaeoecology, morphogroup analysis, Eocene.

\section{INTRODUCTION}

The Tarcău Nappe (Joja, 1955) of the northern Moldavides (Săndulescu, 1984) exposes middle Eocene deposits throughout a relatively large area between Suceava and Moldova valleys. This study focuses on three representative sections of middle Eocene bathyal deposits cropping out along the Brodina Valley (two sections: BV1 - N47.8320, E25.41171, and BV2 - N47.80787, E25.33287 - Fig. 1) and Voroneţ Valley (N47.30196, E25.52240). The reason for treating all three sections in one study was related to similar features of the foraminiferal assemblages.

The studied sections are part of the Tazlău Formation (Atanasiu, 1943; Ionesi, 1971) with facies variations on Brodina and Voroneț valleys due to different geotectonic settings (Săndulescu, 1984); these facies variations can be observed also in the distribution of the foraminiferal assemblages.

The studied sections consist of medium-grained siliciclastic turbidites with Tb-c and Tc-e divisions of Bouma sequence corresponding to the middle part of turbiditic fans.

The objectives of this study are to describe the assemblages of foraminifera from the three sections; to create a quantitative and qualitative description of these assemblages; to describe their morphology and paleoecology in order to establish the biostratigraphy and to interpret the paleoenvironmental settings in the studied areas. This study is part of an extended research in the northern Tarcău Nappe, aimed to obtain a clear picture of the spatial distribution and evolution of paleoenvironmental parameters under the influence of the turbiditic flows and of the sedimentary input.

\section{MATERIAL AND METHODS}

The first studied section is located near the Brodina village on the upper course of the Brodina Valley (BV1 - Fig. 1). Eighteen samples were collected from the outcrop made of alternating decimetric bedded green sandstones and clays in the basal part and reddish sandstones and clays are characteristic for the upper part (Fig. 2). The second section (BV2 - Fig. 1) is placed upstream of BV1, between the Brodina de Jos and Brodina de Sus villages. Four samples were collected from the decimetric to metric greenish clays intercalated in massive sandstone banks (Fig. 2). South of the above mentioned sections, on the Voroneţ stream (Fig. 2), we collected two additional samples from the greenish mudstones intercalated in the sandstones of a strongly tectonized turbidite section.

Samples (250 $\mathrm{g}$ of sediment) were processed using the standard micropaleontological methods (Armstrong and Brasier, 2005) and collected from a $63 \mu \mathrm{m}$ mesh sieve. Where possible, more than 300 specimens of foraminifera were picked. Primary identification was done under the stereomicroscope, while several specimens were examined in detail with a scanning electron microscope at the Electron Microscopy Center of the Babeş-Bolyai University. Quantitative data were calculated for the foraminiferal assemblages using the computer software PAST (Hammer et al., 2001):

- Fisher's $\alpha$ diversity index - in order to predict the number of species in a population which are represented by one individual, two individual, etc.

- Shannon Weaver index - taking into account both the number of species and the distribution of the individuals 


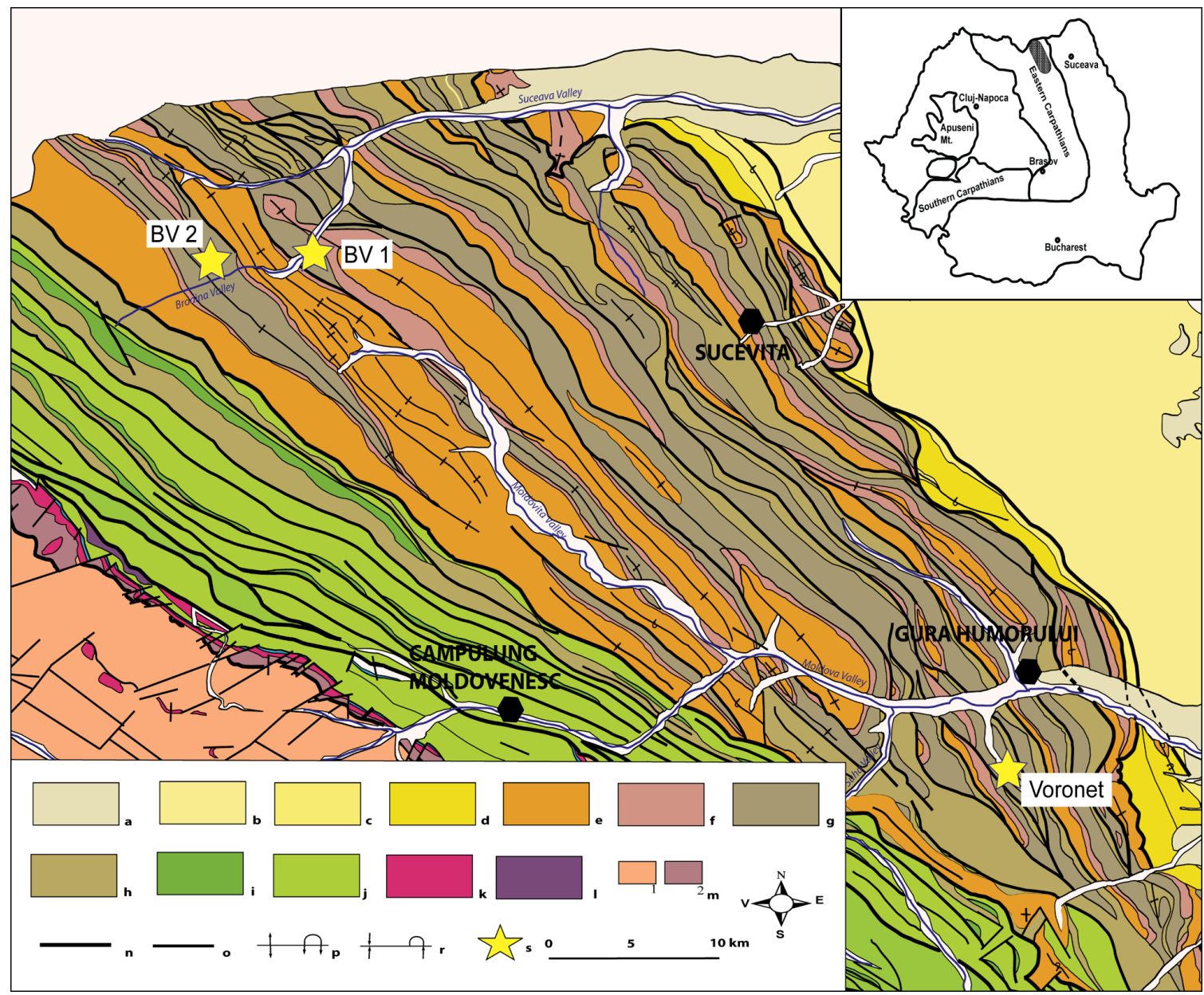

Fig. 1. Location of the investigated sections. a: Quaternary, $b$ : Upper Miocene, c: Middle Miocene, d: Lower Miocene, e: Oligocene, f: Upper Eocene, g: Paleocene - Eocene, h: Upper Cretaceous - Paleocene, $i$ : Upper Cretaceous, $j$ : Lower Cretaceous, $k$ : Triassic, l: Mesozoic magmatites, $m$ : Paleozoic metamorphic rocks $n$ : faults, o: digitations, p: anticline (symmetrical, overturned), $r$ : syncline (symmetrical, overturned), s: location of the investigated section (modified after the Geological Map of Romania, 1:200.000, Rădăuţi sheet; Joja et al., 1968).

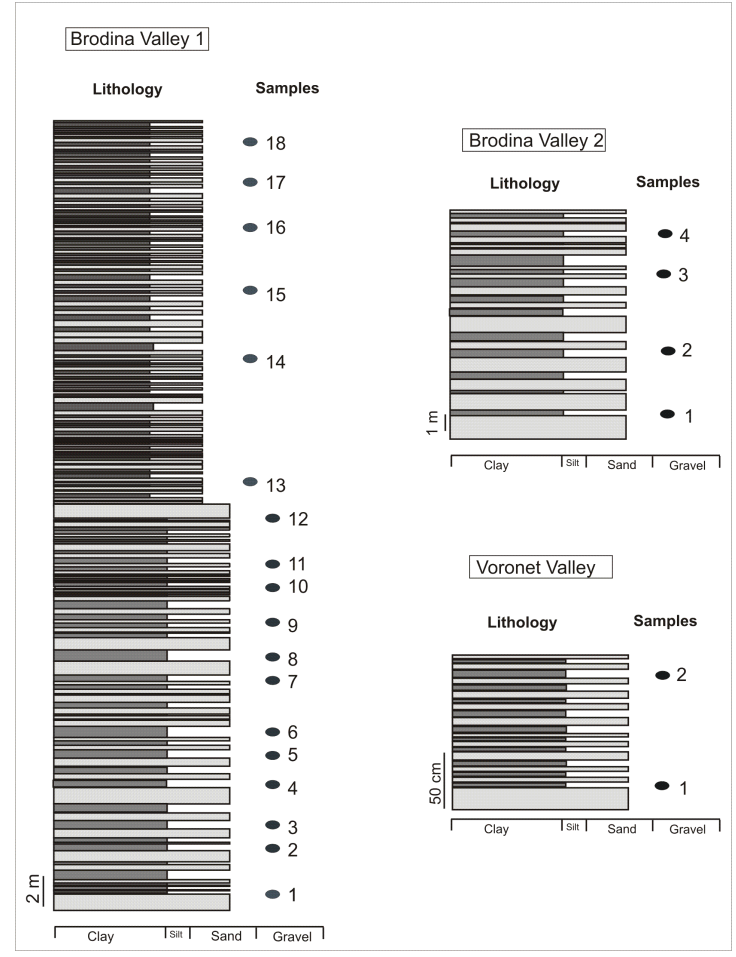

Fig. 2. Sedimentary logs of the studied sections. 
among species (Murray, 1991). Species with low frequencies contribute little to the value of diversity. The maximum value of the diversity occurs when all species have equal frequencies (Buzas and Gibson, 1969).

- Evenness - in order to measure the distribution of individuals among the species in an assemblage.

- Simpson index (1-Dominance) - for estimating the probability that two individuals from an assemblage belong to different species.

Palaeoecological methods also included the analysis of agglutinated foraminifera morphogroups (Corliss, 1985; Jones and Charnok, 1985; Corliss and Chen, 1988; Nagy et al., 1995; Van der Akker et al., 2000; Kaminski and Gradstein, 2005; Cetean et al., 2011; Murray et al., 2011; Setoyama et al., 2011, 2013). The lithologic log was drawn using the StratDraw application (Hoelzel, 2004), while the abundance graphics with GpalWin (Goeury, 1997).

Tubular tests were counted as one individual each for the Brodina Valley 2 and Voroneț sections, while for the Brodina Valley 1, where the tubular forms were fragmented, were counted as 3 pieces for one individual. The biostratigraphical interpretation is based on the agglutinated foraminifera zonations proposed by Morgiel and Olszewska (1981) and Kaminski and Gradstein (2005).

\section{RESULTS}

\section{Composition of foraminiferal assemblages}

Most samples (except for sample 3 from the BV2 section) contain abundant foraminifera assemblages (Appendix 1), with moderate to good preservation. As opposed to BV2 (where the assemblages are made of agglutinated taxa only), benthic and planktic foraminifera were also identified at BV1 and Voroneţ in lower proportions. Most common species are Nothia excelsa, Rhabdammina sp., Psammosiphonella cylindrica, Saccammina sp., Reophax duplex, R. globosus, R. pilulifer, Trochamminoides subcoronatus, T. variolarius, Reticulophragmium amplectens and Haplophragmoides horridus; less represented are: Ammodiscus latus, Reophanus berggreni, Eratidus gerochii and Haplophragmoides parvulus. The assemblages in all investigated sections occur in fine grained turbidites and are dominated by cosmopolitan coarse grained agglutinated taxa.

\section{Foraminiferal morphogroups and diversity analyses}

Morphogroup and diversity analyses were applied to middle Eocene foraminifera for palaeoenvironmental interpretation in the northern Tarcău Nappe. Morphogroup analyses are based on functional morphology stating that species with distinct test shapes have different habitats and feeding strategies (Corliss, 1985; Jones and Charnock, 1985; Murray et al., 2011). Jones and Charnock (1985) showed that the general morphology of the foraminiferal test is related to the preferred ecological niches, therefore foraminifera can be divided into morphotypes. Their scheme has been modified and applied in palaecological studies by further authors (Nagy et al., 1995; Bąk et al., 1997; Peryt et al., 1997, 2004; Van der Akker et al., 2000, Szydło, 2004, 2005; Lemańska, 2005; Reolid et al., 2008; Kender et al., 2009; Cetean et al., 2011; Murray et al., 2011; Setoyama et al., 2011; Bindiu and Filipescu, 2011; Bindiu et al., 2013, Setoyama et al., 2013).
The agglutinated foraminiferal morphogroup scheme used in this research is based on the work of Cetean et al. (2011) and Setoyama et al. (2013).

All agglutinated foraminifera morphogroups are present in the assemblages from the three studied sections (Fig. 3). M1 morphogroup (tubular forms), represented by suspension feeders, is poorly represented in marginal marine areas and very abundant in middle and lower bathyal zones. This morphogroup is common in deep marine environments with low organic matter flux (Kaminski and Gradstein, 2005; Cetean et al., 2011; Setoyama et al., 2011, 2013); it can be also very abundant in bathyal environments with high organic flux and low oxygen values (e.g., modern day species of the genus Bathysiphon - Koho, 2008 and extinct taxa including Nothia robusta and N. excelsa - Kender et al., 2008).

The M2 morphogroup (globular, rounded trochospiral and streptospiral, planoconvex trochospiral and elongate keeled tests) is characterized by suspension and/or deposit feeders from the marginal marine to abyssal environments (Setoyama et al., 2013). The M3 epifaunal morphogroup (flattened planispiral, irregular, trochospiral and streptospiral test form) have an active and passive feeding habit; morphotype M3a occurs in lagoon to abyssal environments while morphotypes $\mathrm{M} 3 \mathrm{~b}$ and M3c are common in deep-water environments (Nagy et al., 1995). The M4 morphogroup (M4a - epifauna and/or shallow infauna with rounded planispiral tests; M4b elongated deep infauna) consists of active deposit feeders, which are good indicators of increased organic flux (Nagy et al., 1995, 1997).

A high abundance of M1 (tubular forms of Nothia excelsa), but low diversity (Fig. 3) was observed in sample 8 of BV1. Morphogroups are evenly distributed in the other samples and the diversity is moderate (Fig. 4).

M1 morphogroup and M4b morphotype (elongate infaunal forms) are present in relatively high and similar proportions while the other morphogroups display small variations in BV2 and Voroneț. The diversity (Fig. 4) is moderate (Fisher $\alpha$ : 11.31-15.36; Shannon Weaver: 2.87 - 3.29; Eveness (0.79 - 0.85) and Simpson: 0.84-0.94).

\section{Biostratigraphy}

Based on the presence of Ammodiscus latus, Reticulophragmium amplectens, Haplophragmoides parvulus, Spirosigmoilinela compressa and Psamminopelta gradseini, the assemblages belong to the upper part of the middle Eocene in all three sections. These taxa are well known to have their first occurrence in the middle Eocene (Mjatliuk, 1970; Morgiel and Olszewska, 1981; Geroch and Nowak, 1984; Kaminski et al., 1988, 1989; Olszewska, 1997; Kaminski and Gradstein, 2005). Reophax pilulifer is present in relatively high proportions ( $13 \%$ from the assemblages) (mostly at BV1 and Voronet); the bioevent is typical for the upper part of the middle Eocene and was also noticed in the Polish Carpathians (Morgiel and Olszewska, 1981; Cieszkowski et al., 2011).

A relatively high number of Reticulophragmiunm amplectens individuals were observed at the Voronet section. The first occurrence this taxon is known as middle Eocene (Kaminski and Gradstein, 2005); its abundance defines the middle Eocene $R$. amplectens Zone mentioned by Joja et al. (1963), Agheorghiresei at al. (1967), Bratu 


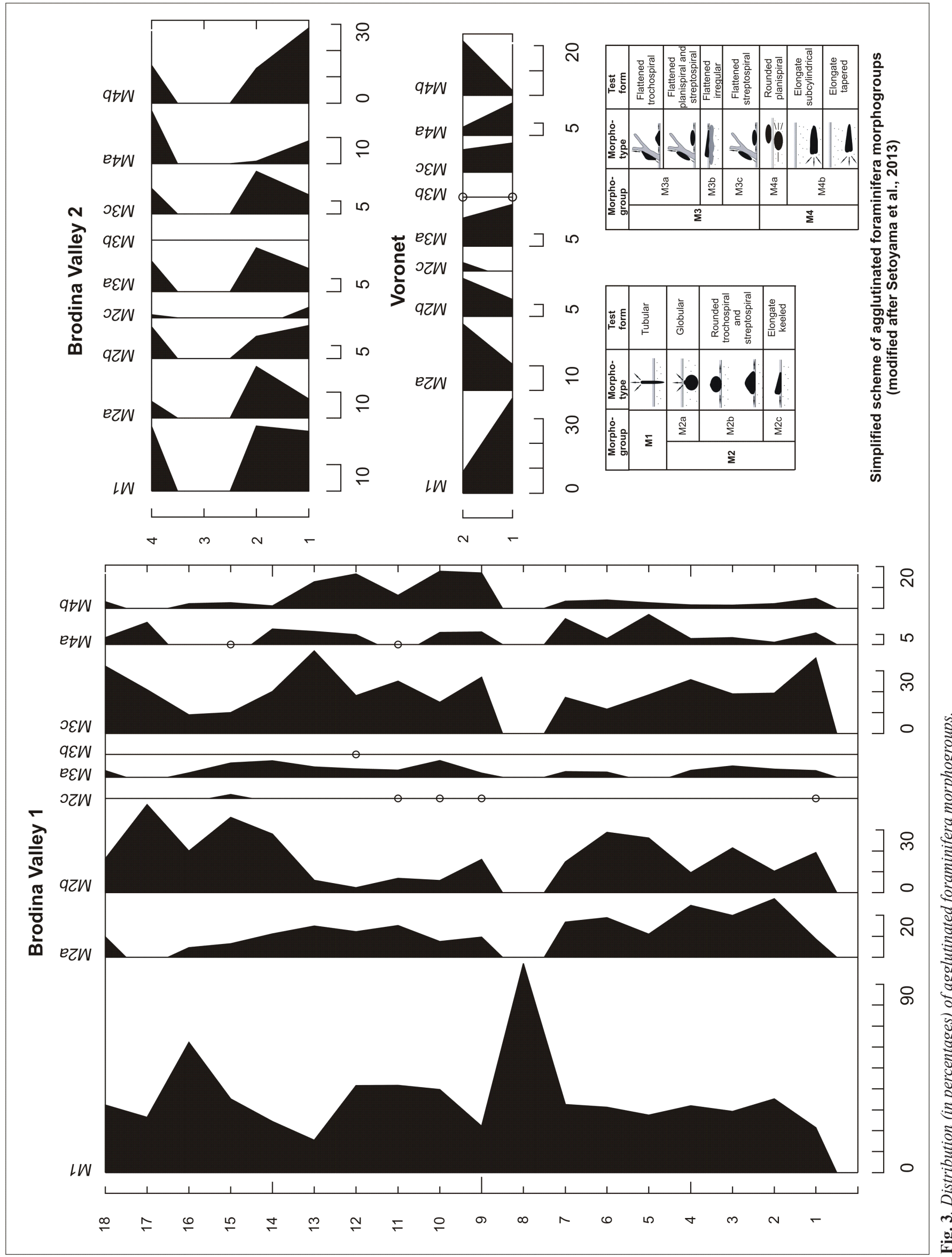




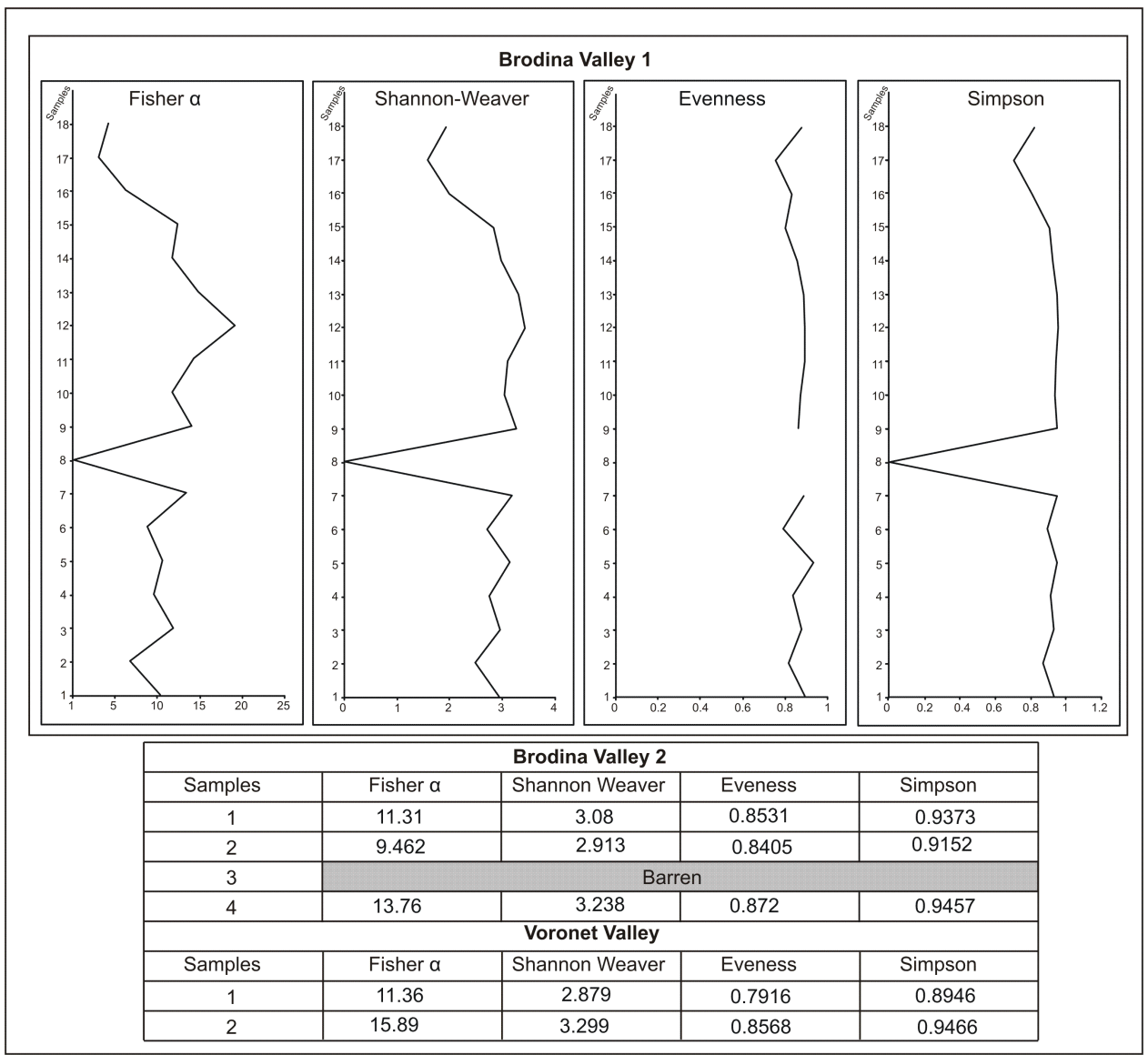

Fig. 4. Diversity indexes at Brodina Valley 1, Brodina Valley 2 and Voronet sections.

(1975), and Săndulescu et al. (1987) in the Romanian Carpathians, and by Geroch and Nowak (1984) in the Polish Carpathians. Gradstein et al. (1994) extended the range of the $R$. amplectens Zone into the late Eocene for the North Sea and Labrador Shelf. Unfortunately, planktonic foraminifera (Acarinina sp., Globigerina sp. and Subbotina sp.) occur only in sample 2 of the Voroneț section and are poorly preserved; thus the application of the biozonations based on planktonic foraminifera cannot be applied for this study.

\section{DISCUSSION AND INTERPRETATION}

Distribution of the morphogroups in BV1 section showed significant proportions of M2a (globular forms of Saccammina, Psammosphaera), M2b (rounded trochospiral and streptospiral taxa - Recurvoides spp.) and M3c (flattened streptospiral forms of Paratrochamminoides and Trochamminoides) morphogroups in the basal and upper part of the section.

This suggests stable palaeoenvironmental conditions with relatively high organic matter content and hypoxic condition. The hypoxic conditions are probably a result of the oxidation of the organic matter causing a depleting of oxygen in the bottom waters. Recent turbidite subenvironments tend to be generally hypoxic as revealed by the presence of high infaunal benthic species (Koho, 2008; Duros et al., 2011, 2013). This interpretation seems to be confirmed by the moderate to high values of diversity indexes in these intervals.
A major change was observed in sample 8 (Fig. 3) where the M1 (represented by Nothia excelsa) is exclusive, suggesting low energy, middle to lower bathyal environments with low organic flux. This is confirmed by the very low values of the diversity recorded in sample 8 (Fig. 4). This change could be interpreted as deep marine paleoenvironments without any turbiditic flow in which the organic matter didn't reach at the sea floor.

M1 (Rhabdammina sp., Nothia excelsa - Plate I) and M4b (Karrerullina coniformis, K. horrida, Reophax pilulifer - PlateII) display similar proportions and distribution in BV2, suggesting stable environmental conditions with moderate organic matter flux and oxygenation.

Distribution of morphogroups and diversity values at Voronet suggest a minor change of the organic matter flux and oxygenation between samples 1 and 2 . While the M1, $\mathrm{M} 2 \mathrm{a}, \mathrm{M} 3 \mathrm{a}$ and M4a participation and the diversity are moderate in sample 1, the percentage of tubular forms (M1) decreases as they are replaced by the M2a (globular forms) and M4b (elongate and subcylindrical forms) in sample 2 and the diversity is higher. This change suggests a higher content of nutrients and hypoxic conditions on the substrate for the second sample. Favorable conditions are also suggested by a higher diversity and presence of ichnofossils.

For both BV2 and Voroneț sections a recolonisation of the substrate after the deposition of coarser sediments can be suggested by the distribution of the foraminiferal assemblages.

The presence of large size specimens with coarse grained tests and the presence of infaunal groups (Karrerulina 
individuals, Reophax individuals - Plate II) reflect variable conditions in the palaeoenvironments with episodes with an increased supply of clastic material to the sea floor; these conditions are similar with those described for the same age deposits from the Polish Carpathians (Cieszkowski et al., 2011).

Bathymetrically, these foraminiferal assemblages are characteristic for upper to lower bathyal settings; the paleobathymetry is confirmed by the presence of the Psammosphaera irregularis, Placentammina placenta, Reophanus berrgreni, Eratidus gerochi, Haplophragmoides horridus, H. kirki taxa, reported only for this type of environments (Kaminski and Gradstein, 2005). Typical deep water agglutinated foraminifera, the dominance of the tubular forms and the presence of the coarse grained tests allow framing the assemblages into the "flysch-type" agglutinated foraminiferal biofacies, characteristic to the Carpathian basin during the Cretaceous to Oligocene (Kaminski and Gradstein, 2005). The very rare planktonic foraminifera and calcareous benthics (small percentages at Voroneț) also point to deep water settings, probably below the CCD.

\section{CONCLUSIONS}

Biostratigraphic analyses on agglutinated foraminifera from the Brodina Valley and Voroneţ sections (northern Tarcău Nappe of the Eastern Carpathians) demonstrated the late middle Eocene age. The micropaleontological assemblages have a high potential for stratigraphic correlation at regional scale.

The foraminiferal assemblages are dominated by agglutinated species with tubular forms (Psammosiphonella cylindrica, Nothia spp., Bathysiphon sp.), globular (Saccammina spp., Psammosphaera spp.), coiled (Recurvoides spp., Reticulophragmium spp.) and flattened streptospiral (Paratrochamminoides spp., Trochamminoides spp.).

The foraminiferal assemblages are typical for "flyschtype" biofacies, characteristic to upper bathyal to lower bathyal settings, with turbiditic and hemipelagic deposition. The dominance of agglutinated foraminifera suggests deposition below the CCD.

The irregular morphotype distribution, combined with fluctuating diversity values along the sections suggest changes in the amount of oxygen, organic matter and energy at the sea floor, probably caused by the palaeoenvironmental instability typical for the turbiditic systems.

Acknowledgments. This paper is a result of a doctoral research made possible by the financial support of the Sectoral Operational Programme for Human Resources Development 2007-2013, co-financed by the European Social Fund, under the project POSDRU/159/1.5/S/133391 - "Doctoral and postdoctoral excellence programs for training highly qualified human resources for research in the fields of Life Sciences, Environment and Earth". Raluca Bindiu thanks to Grzybowski Foundation for the financial support provided by "The Brian J. O'Neill Memorial Student Grant-in-aid for $\mathrm{PhD}$ Research in Stratigraphic Micropalaeontology". Sincere thanks go to anonymous reviewers for their critical comments and suggestions, which helped us to improve the manuscript.

\section{REFERENCES}

Agheorghiresei, V., Băncilă, I., Costea, I. \& Roşca, A. 1967, Contributions to the stratigraphy of the Carpathian Flysch. Dări de Seamă ale Şedinţelor Comitetului Geologic, 53 (1): 251-273.

Armstrong, H.A., Brasier, M.D. 2005, Microfossils (2 ${ }^{\text {nd }}$ Ed.). Blackwell Publishing, Oxford, 304 p.

Atanasiu, I. 1943, Les Facies du Flysch marginale dans le pertie moyenne des Carpates Moldaves. Analele Institutului Geologic al României, 22: 149-146.

Bąk, K., Bąk, M., Geroch, S. \& Manecki, M. 1997, Biostratigraphy and paleoenvironmental analysis of benthic foraminifera and radiolarians in Paleogene variegate shales in the Skole Unit, Flysch Carpathians. Annales Societatis Geologorum Poloniae, 67: 135-154.

Bindiu, R., Filipescu, S. 2011, Agglutinated Foraminifera from the Northern Tarcău Nappe (Eastern Carpathians, Romania). Studia UBB Geologia, 56 (2): 31-41. http://dx.doi.org/10.5038/1937-8602.56.2.4

Bindiu, R., Filipescu, S. \& Bălc, R. 2013, Biostratigraphy and paleoenvironment of the Upper Cretaceous deposits in the northern Tarcău Nappe (Eastern Carpathians) based on foraminifera and calcareous nannoplankton. Geologica Carpathica, 64 (2): 117-132.

http://dx.doi.org/10.2478/geoca-2013-0008

Bratu, E. 1975, Coupe du Maestrichtien a l'Oligocéne inferiéure dans le Flysch externe de Cuejdiu (Bassin de la Bistriţa). 14 $4^{\text {th }}$ European Micropaleontological Colloquium, Bucureşti, 135-141.

Buzas, M.A., Gibson, T.G. 1969, Species diversity: benthonic foraminifera in Western North Atlantic. Science, 163: 72-75. http://dx.doi.org/10.1126/science.163.3862.72

Cetean, C., Bălc, R., Kaminski, M.A. \& Filipescu, S. 2011, Integrated biostratigraphy and palaeoenvironments of an upper Santonian - upper Campanian succession from the southern part of the Eastern Carpathians, Romania. Cretaceous Research, 32: 575-590.

http://dx.doi.org/10.1016/j.cretres.2010.11.001

Cieszkowski, M., Waśkowska, A. \& Kaminski, M. 2011, Deep water agglutinated foraminifera in Paleogene hemipelagic sediments of the Magura Basin in the Sucha Bezkidizka area - variegated shales of the Łabowa Shales Formation. In: Integrating Microfossil Records from the Oceans and Epicontinental Seas (Bąk, M., Kaminski, M.A., Waśkowska, A., Eds.), 2011. Grzybowski Foundation Special Publication, 17: 3-63.

Corliss, B.H., 1985, Microhabitats of benthic foraminifera within deep-sea sediments. Nature, 314: 435-438. http://dx.doi.org/10.1038/314435a0

Corliss, B.H., Chen, C. 1988, Morphotype patterns of Norwegian Sea deep-benthic foraminifera and ecological implications. Geology, 16: 716-719. http://dx.doi.org/10.1130/0091-7613(1988)016<0716: MPONSD $>2.3 . \mathrm{CO} ; 2$

Duros, P., Fontanier, C., Metzger, E., Pusceddu, A., Cesbron, F., de Stigter, H.C., Bianchelli, S., Danovaro, R. \& Jorissen, F.J. 2011, Live (stained) benthic foraminifera in the Whittard Canyon, Celtic margin (NE Atlantic). Deep Sea Research, 58: 128-146.

http://dx.doi.org/10.1016/j.dsr.2013.01.004 
Duros, P., Fontanier, C., Metzger, E., Cesbron, F., Deflandre, B., Schmidt., S., Buscail., R., Zaragosi, S., Kerhervé, P., Rigaud, S., Delgard, M.L. \& Jorissen, F.J. 2013, Live (stained) benthic foraminifera from the Cap-Ferret Canyon (Bay of Biscay, NE Atlantic): A comparison between the canyon axis and the surrounding areas. Deep Sea Research, Part I: Oceanographic Research Papers, 74: 98-114. http://dx.doi.org/10.1016/j.dsr.2013.01.004

Geroch, S., Nowak, W. 1984, Proposal of zonation for the late Tithonian-late Eocene, based upon arenaceous foraminifera from the outer Carpathians, Poland. In: Benthos ' $83,2^{\text {nd }}$ International Symposium on Benthic Foraminifera, (Pau 1983) (Oertli, H.J. Ed.), Elf Aquitaine, Esso REP, and Total CFP, Pau and Bordeaux, 225-239.

Goeury, C. 1997, GpalWin: gestion, traitement et représentation de la paléoécologie. $X V$-ème Symposium de l'APLF (Association des Palynologues de Langue Française), Université Claude Bernard, Lyon. 31 p.

Gradstein, F.M., Kaminski, M.A., Berggren, W.A. \& D’Iorio, M.A. 1994, Cenozoic biostratigraphy of the Central North Sea and Labrador Shelf. Micropaleontology, 40: 1-152. http://dx.doi.org/10.2307/1485906

Hammer, O., Harper, D.A.T. \& Ryan, P.D. 2001, PAST: Paleontological statistics software package for education and data analysis. Palaeontologia Electronica, 4 (1): 1-9.

Hoelzel, M. 2004, StratDraw: automatic generation of stratigraphic sections from tabulated field data. Computers and Geociences, 30: 785-789.

http://dx.doi.org/10.1016/j.cageo.2004.05.004

Ionesi, L. 1971, The Paleogene flysch from the Moldova River basin. Romanian Academy Publishing House, Bucharest, $250 \mathrm{p}$.

Joja, Th. 1955, External flysch and the Miocene between Falcău and Bilca and from SV from Voitinelu. Dări de Seamă ale Şedinţelor Comitetului Geologic of R.P.R., 39: 86-300.

Joja, Th., Cosma, V. \& Dumitrescu, Z. 1963, Horizontality of the external flysch between Suceava and Suceviţa and their micropaleontological content. Association des géologie Carpato-Balcanic, Congress V, 3 (1): 221-252.

Joja, Th., Alexandrescu, Gr., Bercia, I., Mutihac, V. \& Dimian, M. 1968, Geological Map of Romania, 1: 200.000, Rădăuţi Sheet, Geological Institute, Bucharest.

Jones, R.W, Charnock, M.A. 1985, “Morphogroups”of agglutinating foraminifera. Their life position, feeding habitats and potential applicability in (paleo)ecological studies. Revue de Paleobiologie, 4: 311-320.

Kaminski, M.A., Gradstein, F.M., Berggren, W.A., Geroch, S. \& Beckmann, J.P. 1988, Flysch-type agglutinated foraminiferal assemblages from Trinidad: taxonomy, stratigraphy and paleobathymetry. Abhandlungen Geoischen Bundesanstalt, 41: 155-227.

Kaminski, M.A., Gradstein, F.M. \& Berggren, W.A. 1989, Paleogene benthic foraminifer biostratigraphy and paleoecology at Site 647, Southern Labrador Sea. Proceedings of the Ocean Drilling Program, Scientific Results, 105: 705-730.

http://dx.doi.org/10.2973/odp.proc.sr.105.124.1989
Kaminski, M.A., Gradstein, F. M. (eds.), Bäckström, S., Berggren, W. A., Bubík, M., Carvajal-Chitty, H., Filipescu, S., Geroch, S., Jones, D. S., Kuhnt, W., McNeil D., H., Nagy, J., Platon, E., Ramesh, P., Rögl, F., Thomas, F. C., Whittaker, J. E. \& Yakovleva-O’Neil, S. 2005, Atlas of Paleogene cosmopolitan deep-water agglutinated foraminifera. Grzybowski Foundation, 547 p. http://dx.doi.org/10.2113/gsmicropal.52.6.555

Kender, S., Kaminski, M.A. \& Jones, B.W. 2008, Oligocene deep-water agglutinated foraminifera from the Congo Fan, offshore Angola: Palaeoenvironments and assemblage distributions. In: Proceedings of the Seventh International Workshop on Agglutinated Foraminifera (Kaminski, M.A., Coccioni, R., Eds.), Grzybowski Foundation. Special Publication, 13: 107-156.

Kender, S., Kaminski, M.A. \& Jones, R.W. 2009, Early to middle Miocene foraminifera from the deep-sea Congo Fan, offshore Angola. Micropaleontology, 54: 477-568.

Koho, K.A. 2008, The dynamic balance between food abundance and habitat instability: benthic foraminifera of Portuguese margin canyons. Geologica Ultraiectina, 286: $1-126$.

Lemańska, A. 2005, Comparison of deep-water agglutinated foraminifera from the hemipelagic variegated shales (Lower Turoniam-Lower Santonian) and the turbiditic Godula beds (Upper Santonian-Campanian) in the LanckoronaWadowice area (Silesian Unit, Outer Carpathians, Poland). Studia Geologica Polonica, 124: 259-272.

Mjatliuk, E.V. 1970, Foraminifera of the flysch deposits of the eastern Carpathians. Trudy Vsesoyuznogo NauchnnoIssledovatel'skogo Geologorazvedochnogo Instituta VNIGRI, Leningrad, $225 \mathrm{p}$.

Morgiel, J., Olszewska, B. 1981, Biostratigraphy of the Polish external Carpathians based on agglutinated foraminifera. Micropaleontology, 27 (1): 1-24. http://dx.doi.org/10.2307/1485376

Murray, J.W. 1991, Ecology and paleoecology of benthic foraminifera. John Wiley \& Sons, New York, 397 p.

Murray, J.W., Alve E. \& Jones, B. 2011, A new look at modern agglutinated benthic foraminiferal morphogroups: their value in palaeoecological interpretation. Palaeogeography, Palaeoclimatology, Palaeoecology, 309: 229-241. http://dx.doi.org/10.1016/j.palaeo.2011.06.006

Nagy, J., Gradstein, F.M., Kaminski, M.A. \& Holbourn, A.E. 1995, Foraminiferal morphogroups, paleoenvironments and new taxa from Jurassic to Cretaceous strata of Thakkhola, Nepal. In: Proceedings of the Fourth International Workshop on Agglutinated Foraminifera (Kaminski, M.A., Geroch, S., Gasinski, M., A., Eds.). Grzybowski Foundation Special Publication, 3: 181-209.

Nagy, J., Kaminski, M.A., Johnsen, K. \& Mitlehner, A.G. 1997, Foraminiferal, palynomorph, and diatom biostratigraphy and paleoenvironments of the Torsk Formation: A reference section for the Paleocene-Eocene transition in the western Barents Sea. In: Contributions to the Micropaleontology and Paleoceanography of the Northern North Atlantic (Hass, H.C., Kaminski, M.A., Eds.). Grzybowski Foundation Special Publication, 5: 15-38.

Olszewska, B. 1997, Foraminiferal biostratigraphy of the Polish Outer Carpathians: a record of basin geohistory. Annales Societatis Geologorum Poloniae, 67: 325-337. 
Peryt, D., Lahodynsky, R. \& Durakiewicz, T. 1997, Deepwater agglutinated foraminiferal changes and stable isotope profiles across the Cretaceous - Paleogene boundary in the Rotwandgraben section, Eastern Alps (Austria). Palaeogeography, Palaeoclimatology, Palaeoecology, 132: 287-307. http://dx.doi.org/10.1016/S0031-0182(97)00056-4

Peryt, D., Alegret, L. \& Molina, E. 2004, Agglutinated foraminifers and their response to the Cretaceous/ Paleogene (K/P) boundary event at Aïn Settara, Tunisia. In: Proceedings of the Sixth International Workshop on Agglutinated Foraminifera (Bubík, M., Kaminski, M.A., Eds.). Grzybowski Foundation Special Publication, 393-412.

Reolid, M., Rodríguez-Tovar, F.J., Nagy, J. \& Olóriz, F. 2008, Benthic foraminiferal morphogroups of mid to outer shelf environments of the Late Jurassic (Prebetic Zone, Southern Spain): Characterization of biofacies and environmental significance. Palaeogeography, Palaeoclimatology, Palaeoecology, 261: 280-299.

http://dx.doi.org/10.1016/j.palaeo.2008.01.021

Săndulescu, M. 1984, Geotectonics of Romania. Editura Tehnică, Bucureşti. 334 p.

Săndulescu, M., Micu, M. \& Bratu, E. 1987, Stratigraphy of the Eocene Flysch formations of the East Carpathians. In: The Eocene from the Transylvanian Basin, Romania. Geological Formations of Transylvania (Petrescu, I., Ghergari, L., Mészáros, N., Nicorici, E., Eds.). Romania, 159-164.
Setoyama, E., Kaminski, M.A. \& Tyszka, J. 2011, The Late Cretaceous-Early Paleocene palaeobathymetric trends in the southwestern Barents Sea - Palaeoenvironmental implications of benthic foraminiferal assemblage analysis. Palaeogeography, Palaeoclimatology, Palaeoecology, 307 (1-4): 44-58.

http://dx.doi.org/10.1016/j.palaeo.2011.04.021

Setoyama, E., Radmacher, W., Kaminski, M.A. \& Tyszka, J. 2013, Foraminiferal and palynological biostratigraphy and biofacies from a Santonian-Campanian submarine fan system in the Vøring basin (offshore Norway). Marine and Petroleum Geology, 43: 396-408.

http://dx.doi.org/10.1016/j.marpetgeo.2012.12.007

Szydło, A. 2004, The distribution of agglutinanted foraminifera in the Cieszyn Basin, Polish Outer Carpathians. Grzybowski Foundation Special Publication, 8: 461-470.

Szydło, A. 2005, Benthic foraminiferal morphogroups and taphonomy of the Cieszyn beds (Tithonian-Neocomian, Polish Outer Carpathians). Studia Geologica Polonica, 124: 199-204.

Van Der Akker, T., Kaminski, M.A., Gradstein, F.M. \& Wood, J. 2000, Campanian to Palaeocene biostratigraphy and palaeoenvironments in the Foula Basin, west of Shetland Islands. Journal of Micropalaeontology, 19: 23-43. http://dx.doi.org/10.1144/jm.19.1.23 
Plate I.

Fig. 1. - Nothia excelsa (Grzybowski) (Brodina Valley 1) - sample 8;

Fig. 2. - Rhabdammina linearis Brady (Brodina Valley 1) - sample 12;

Fig. 3. - Psammosphaera fusca Schultze (Brodina Valley 2) - sample 1;

Fig. 4. - Ammodiscus tenuissimus Grzybowski (Brodina Valley 2) - sample 2;

Fig. 5. - Psamminopelta gradsteini (Matsunaga) (Brodina Valley 1) - sample 12;

Fig. 6. - Reophanus berggreni Gradstein \& Kaminski (Brodina Valley 1) - sample 9;

Fig. 7. - Saccamminoides carpathicus Geroch (Voroneţ) - sample 1;

Fig. 8. - Hormosina velascoensis (Cushman) (Voroneţ) - sample 1;

Fig. 9. - Paratrochamminoides heteromorphus (Grzybowski) (Brodina Valley 1) - sample 13;

Fig. 10. - Trochamminoides grzybowskii Kaminski \& Geroch (Voroneţ) - sample 1;

Fig. 11. - Praesphaerammina subgaleata (Vašiček) (Voroneţ) - sample 2;

Fig. 12. - Ammobaculites agglutinans (d'Orbigny) (Brodina Valley 1) - sample 7;

Fig. 13. - Reticulophragmium amplectens (Grzybowski) - (Voroneț) - sample 1. 
PLATE I

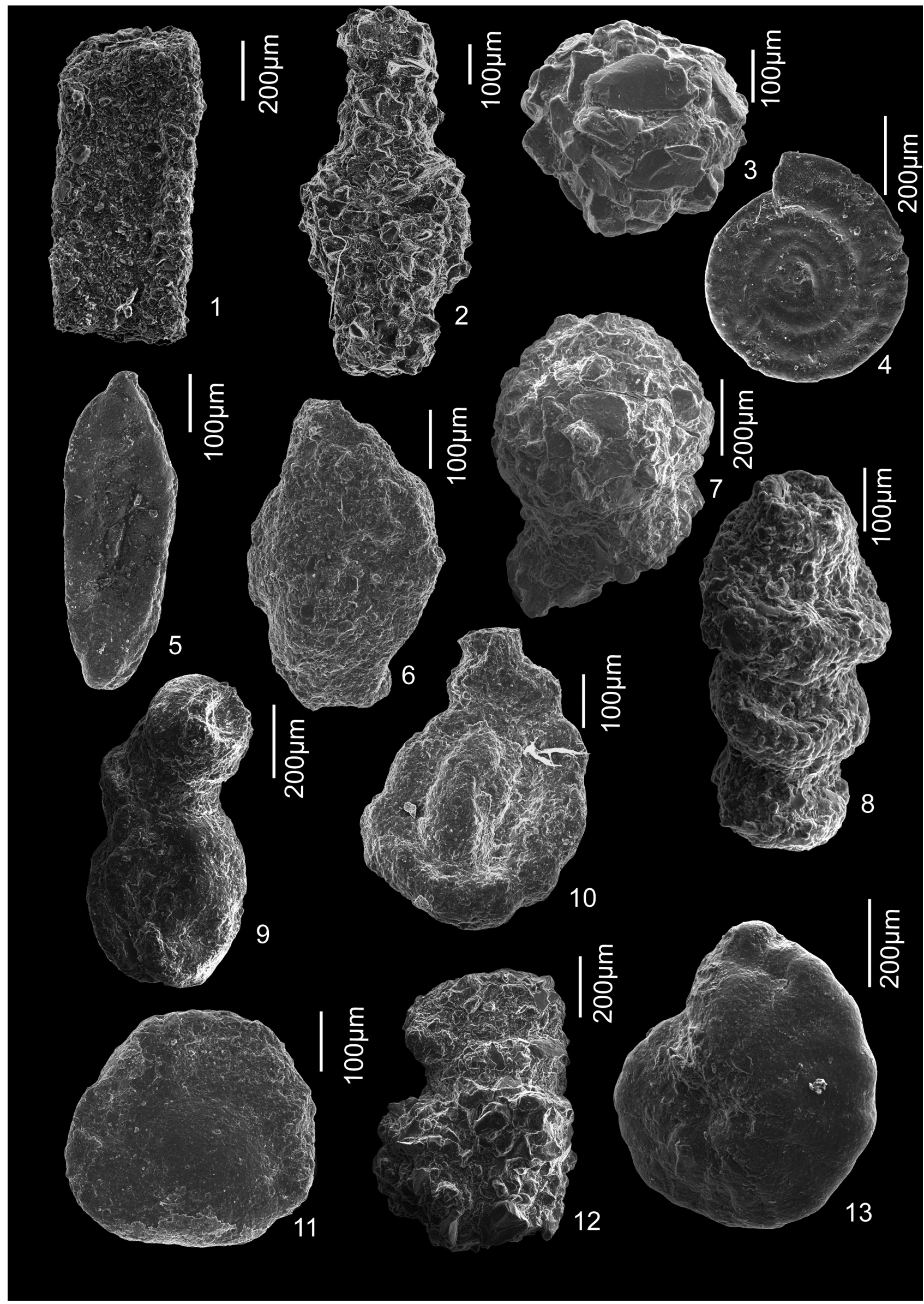


Plate II. (Scale bar - $100 \mu \mathrm{m})$.

Fig. 1. - Rhabdammina sp. (Voroneţ) sample 1;

Fig. 2. - Psammosphaera irregularis (Grzybowski) (Brodina Valley 2) sample 2;

Fig. 3. - Ammodicus cretaceus (Reuss) (Voroneţ) sample 2;

Fig. 4. - Glomospira charoides (Jones \& Parker) (Brodina Valley 1) sample 17;

Fig. 5. - Reophax pilulifer Brady (Brodina Valley 2) sample 1;

Fig. 6. - Haplophragmoides walteri (Grzybowski) (Brodina Valley 1) sample 3;

Fig. 7. - Ammosphaeroidina pseudopauciloculata (Mjatliuk) (Voroneţ) sample 1;

Fig. 8. - Karrerulina coniformis (Grzybowki) (Voroneț) sample 2;

Fig. 9. - Karrerulina horrida (Mjatliuk) (Brodina Valley 2) sample 4;

Fig. 10. - Reticulophragmium amplectens (Grzybowski) (Voroneţ) sample 2. 
PLATE II

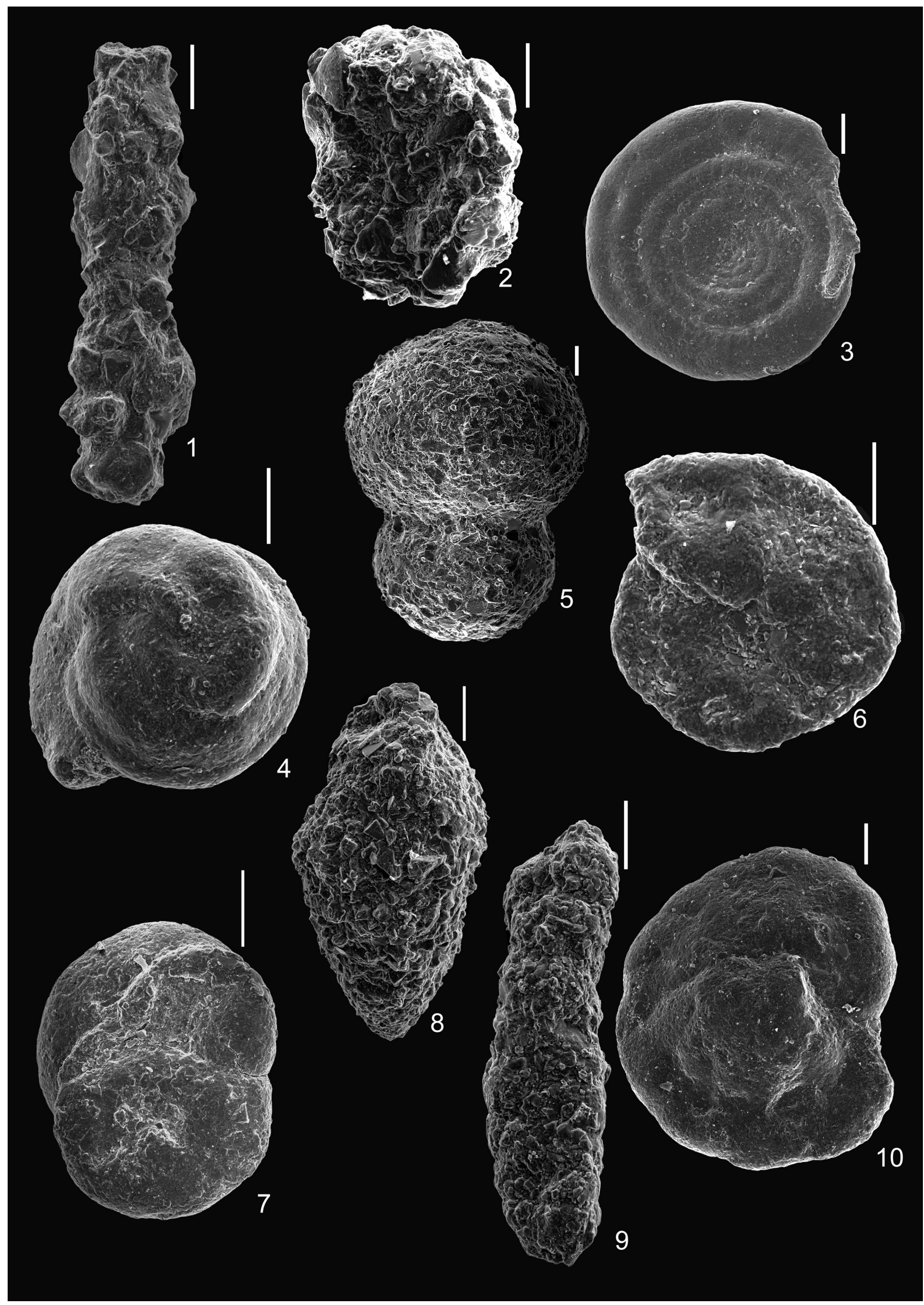




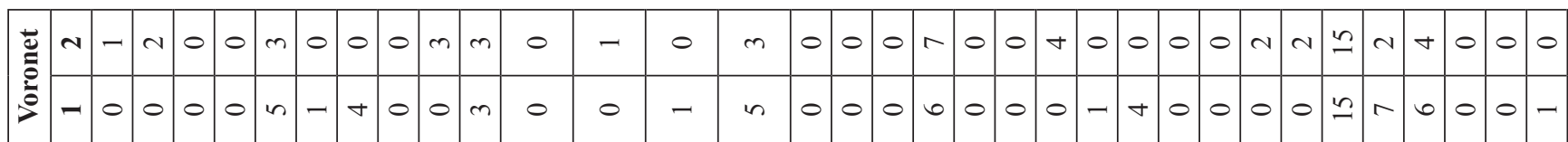

\begin{tabular}{|c|c|c|c|c|c|c|c|c|c|c|c|c|c|c|c|c|c|c|c|c|c|c|c|c|c|c|c|c|c|c|c|}
\hline \multirow{2}{*}{\multicolumn{2}{|c|}{ 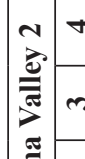 }} & 0 & 0 & 0 & 0 & $\nabla$ & -1 & $m$ & $\begin{array}{lll}0 & \mathrm{~s}\end{array}$ & in & 0 & 0 & 0 & $\simeq$ & 0 & 0 & 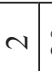 & तి & 0 & 0 & 0 & 0 & -1 & 0 & 0 & 0 & & 0 & 0 & & 0 \\
\hline & & 0 & 0 & 0 & 0 & 0 & 0 & 0.0 & 00 & 0 & 0 & 0 & 0 & 0 & 0 & 0 & 0 & 0 & 0 & 0 & 0 & 10 & 0 & 0 & 0 & 0 & 00 & 0 & 0 & 0 & 0 \\
\hline & \begin{tabular}{|l|}
$N$ \\
\end{tabular} & 0 & 0 & 0 & 0 & 0 & 0 & & $0+$ & $m$ & 0 & 0 & 0 & $r$ & 0 & o & 0 & $\nabla$ & 0 & 0 & 0 & 10 & 0 & 0 & 0 & 0 & & $\mathrm{om}$ & 0 & 0 & - \\
\hline & -7 & 0 & 0 & 0 & 0 & 0 & 0 & $\sim c$ & 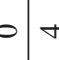 & • & 0 & 0 & 0 & तี & & 0 & 0 & $\infty$ & 0 & c & $c$ & & 0 & 0 & 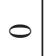 & 0 & & & 0 & 0 & - \\
\hline
\end{tabular}

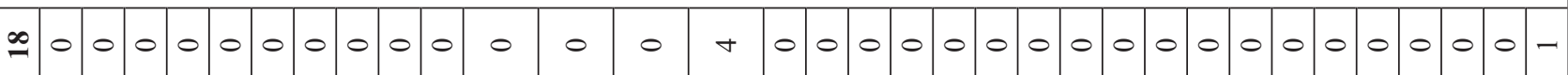

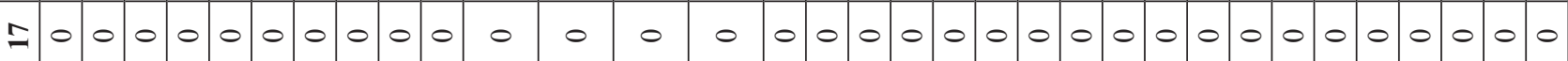

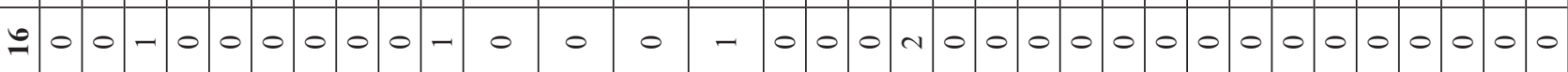

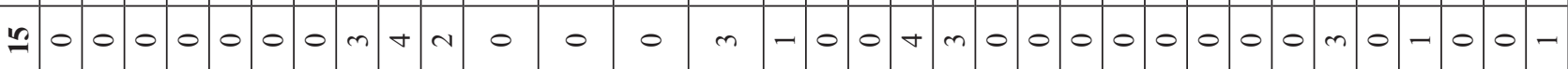

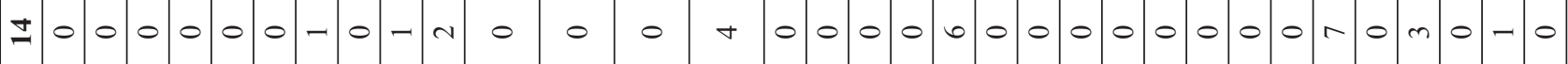

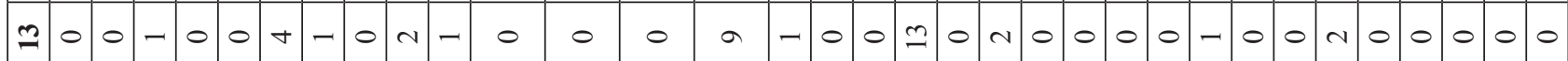

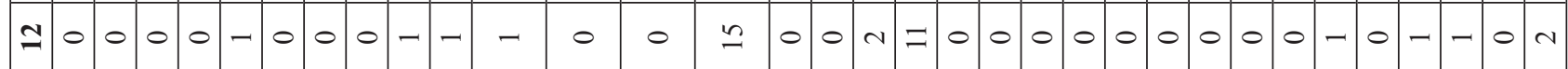

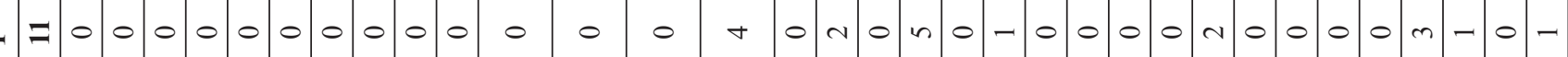

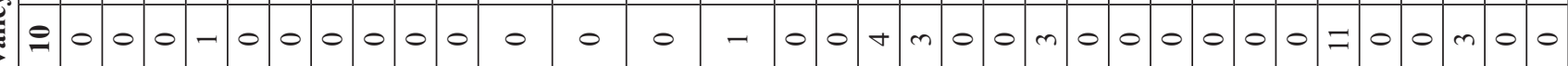

$\begin{array}{lllllllllllllllllllllllllllllllllll}a & 0 & 0 & 0 & 0 & 0 & 0 & 0 & 0 & 0 & 0 & 0 & 0 & 0 & 0 & 0 & 0 & - & 0 & 0 & 0 & 0 & 0 & 0 & - & 0 & 0 & 0 & 0 & 0 & 4 & 0 & 4 & -1\end{array}$

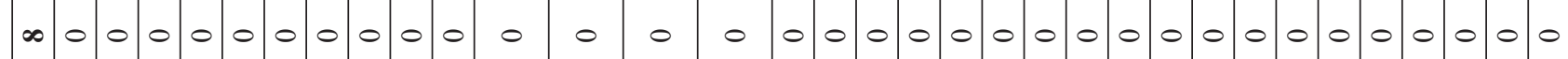
\begin{tabular}{rllllllllllllllllllllllllllllllllll}
\hline & 0 & 0 & - & - & 0 & 0 & 4 & 0 & 0 & 0 & 0 & 0 & 0 & - & 0 & 0 & 4 & 0 & 0 & - & 0 & 0 & 0 & 0 & 0 & 0 & 0 & 4 & 0 & 0 & 0 & 0 & 0
\end{tabular}

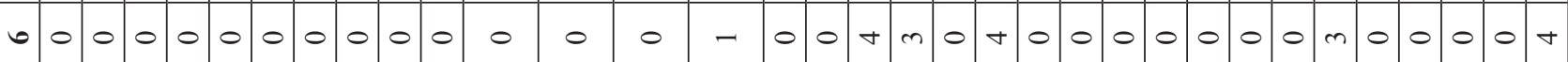

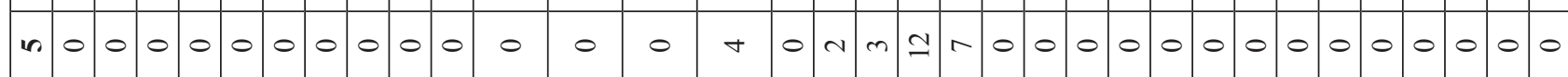

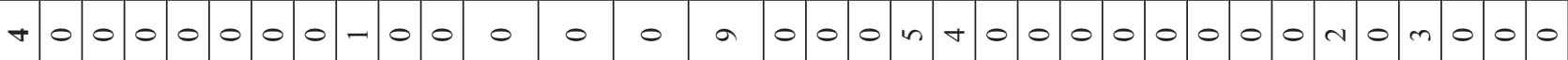

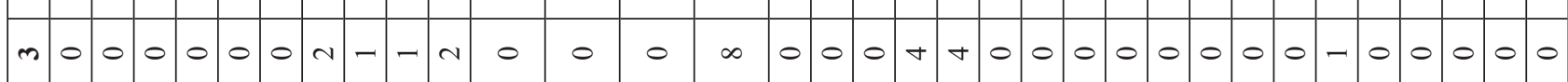
$\begin{array}{llllllllllllllllllllllllllllllllllll}4 & 0 & 0 & 0 & m & 0 & 0 & 0 & 0 & 4 & 0 & 0 & 0 & 0 & 0 & 0 & 0 & 0 & n & 0 & 0 & 0 & 0 & 0 & 0 & 0 & 0 & 0 & m & -1 & 0 & 0 & 0 & -1\end{array}$

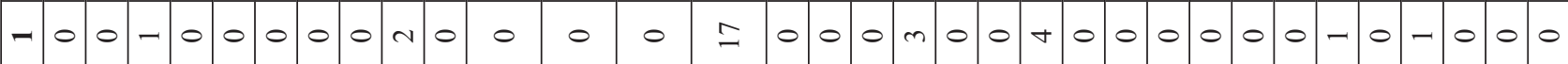

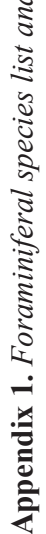

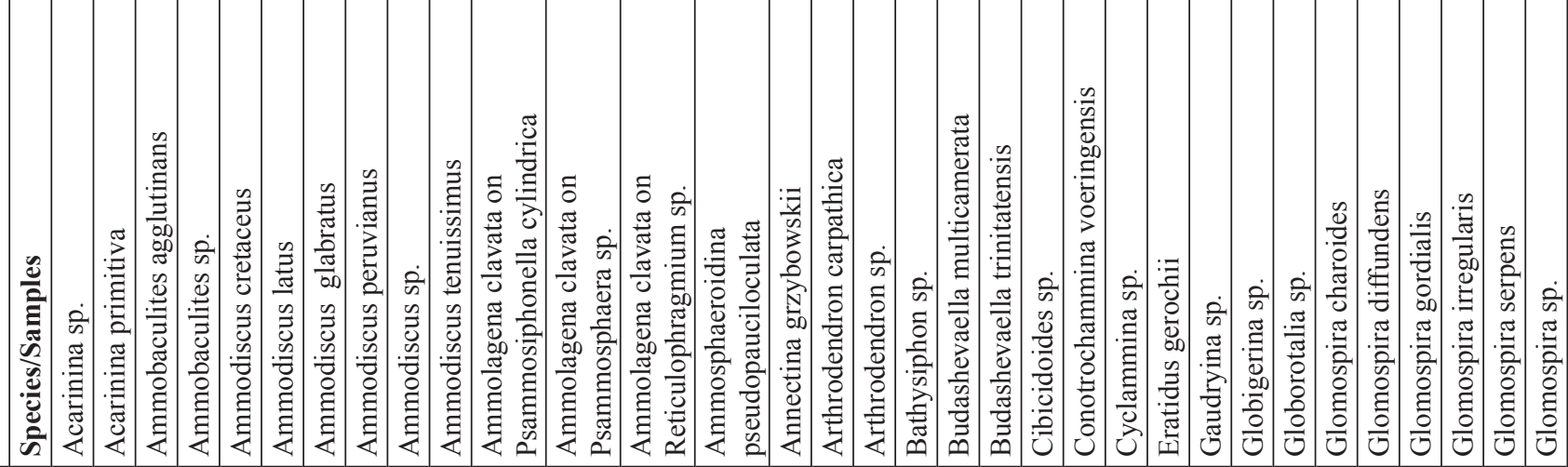


\begin{tabular}{|c|c|c|c|c|c|c|c|c|c|c|c|c|c|c|c|c|c|c|c|c|c|c|c|c|c|c|c|c|c|c|c|c|c|c|c|c|c|}
\hline$n$ & 0 & 0 & 0 & 0 & 0 & 4 & 0 & 0 & - & 0 & 0 & 0 & 0 & 4 & 0 & 0 & 0 & 0 & 0 & 0 & 0 & 0 & 0 & 0 & - & 0 & 4 & 4 & 0 & - & 4 & 4 & 0 & 0 & 0 & 4 & 0 \\
\hline
\end{tabular}

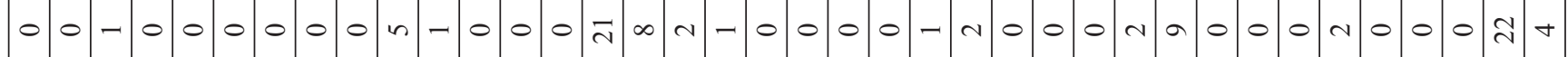

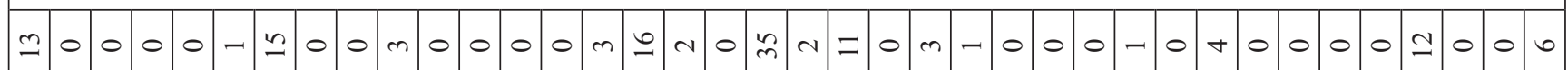

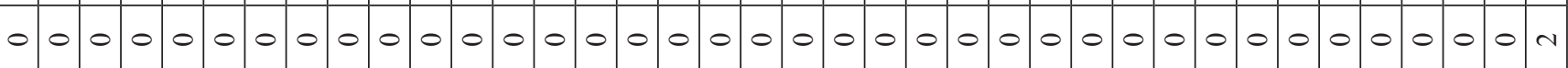

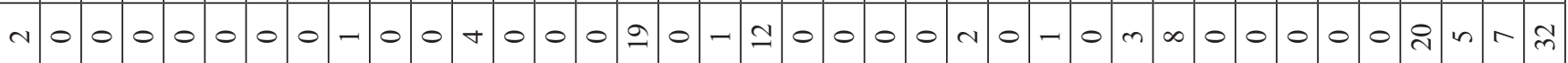

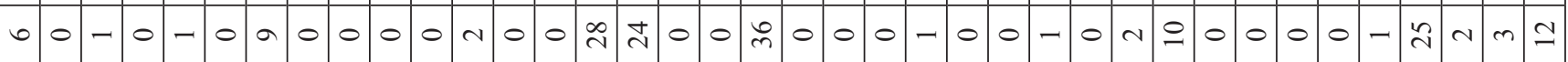

- 0 -

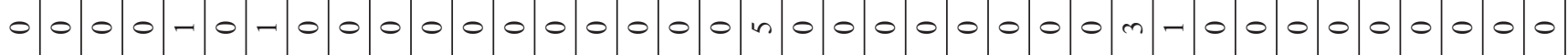

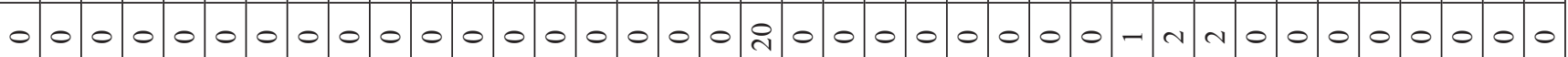

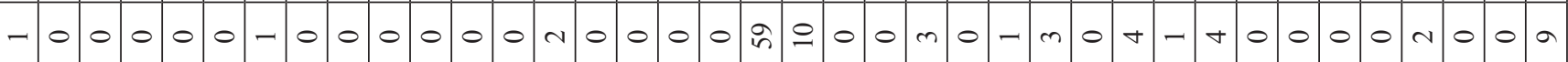

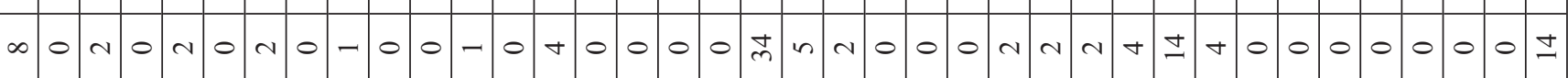

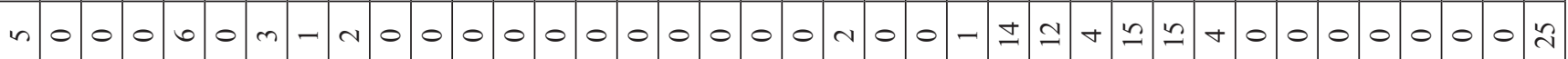

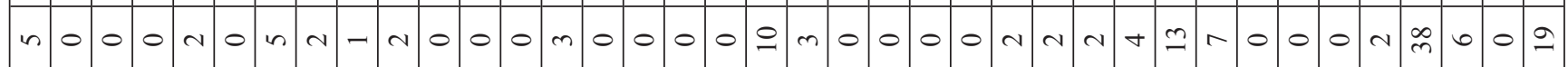

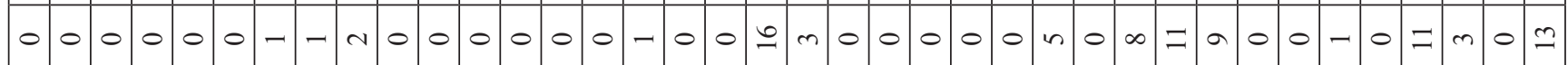

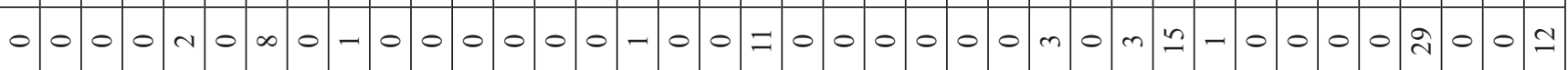

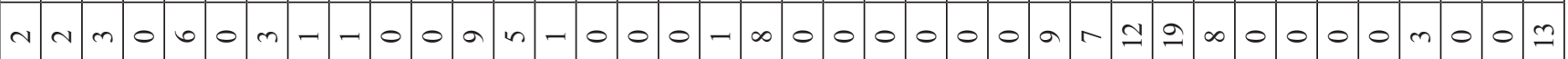

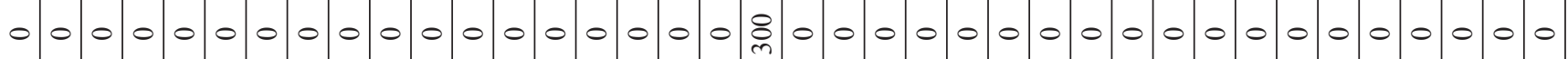

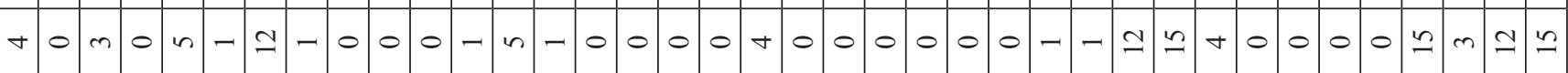

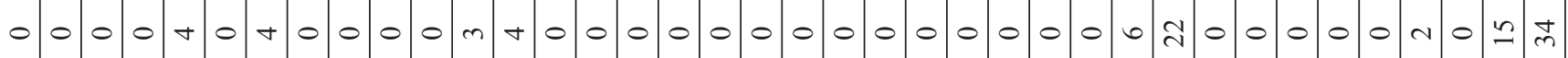

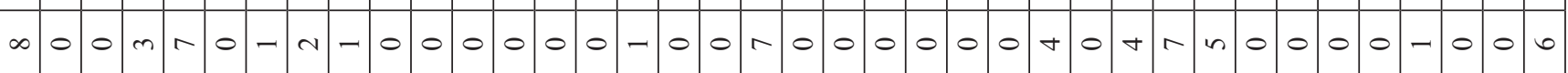

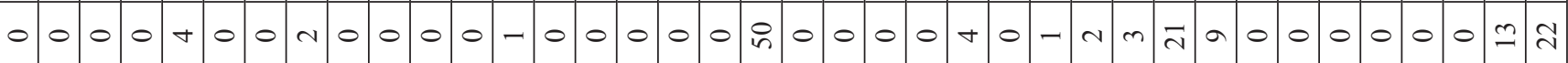
n

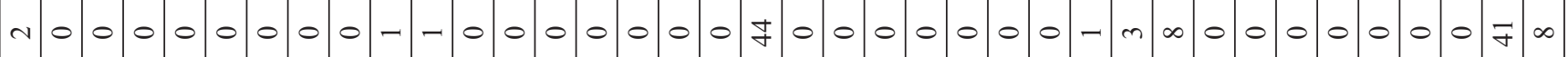

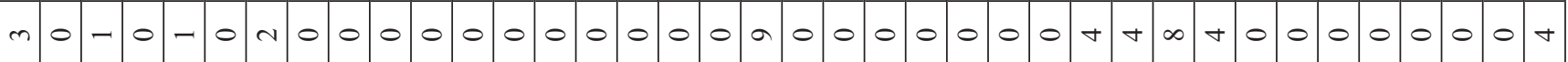

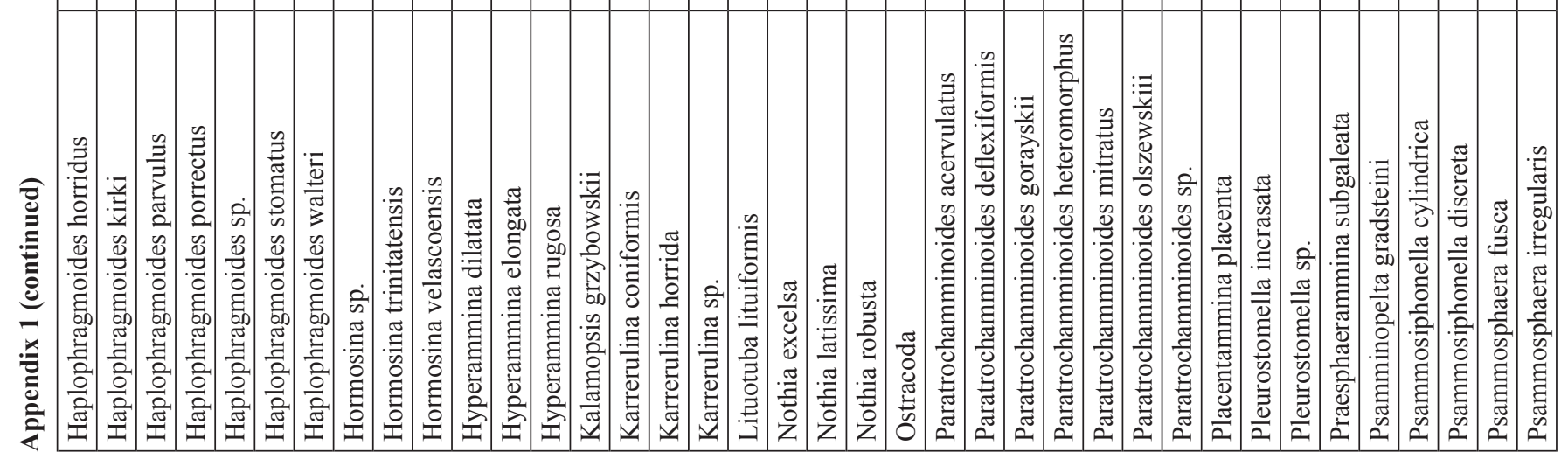




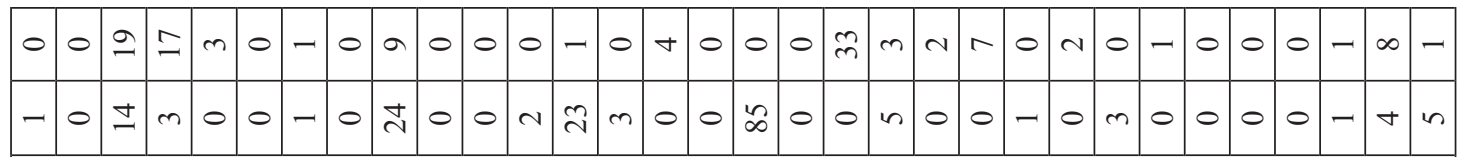

\begin{tabular}{|c|c|c|c|c|c|c|c|c|c|c|c|c|c|c|c|c|c|c|c|c|c|c|c|c|c|c|c|c|c|c|c|}
\hline 0 & 4 & $m$ & 0 & 0 & 0 & 0 & 0 & 0 & - & 0 & 0 & $n$ & 0 & - & 0 & 0 & 0 & - & - & 0 & - & 0 & 0 & $m$ & 0 & 0 & 0 & 0 & 0 & 4 & $n$ \\
\hline
\end{tabular}

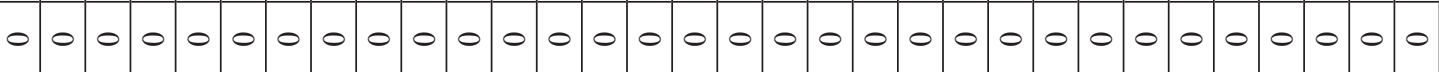

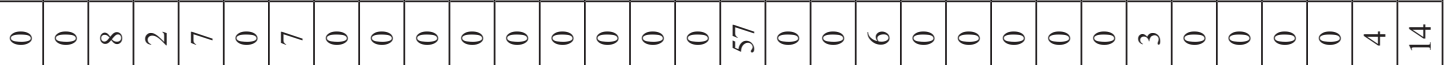

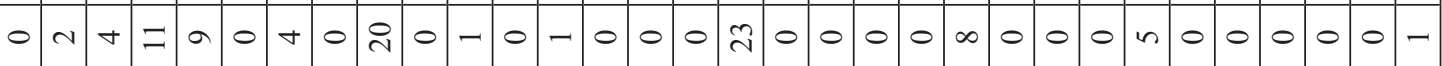

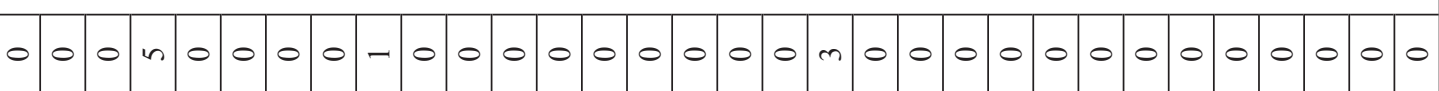

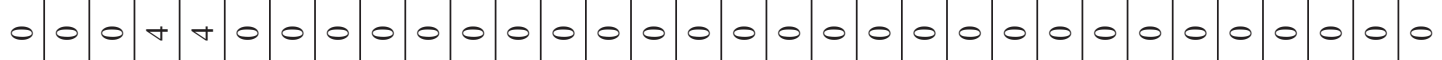

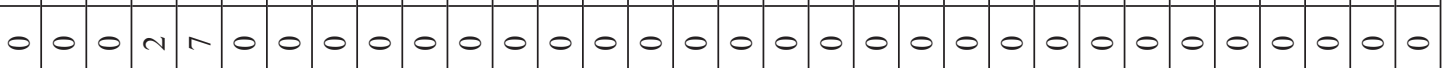

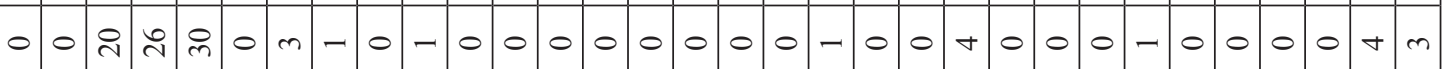

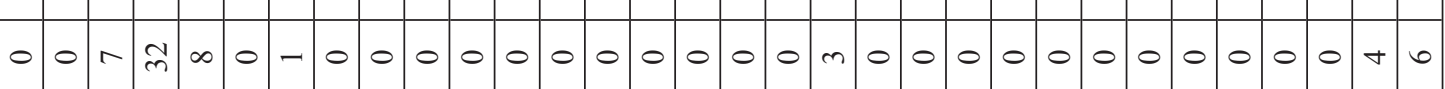

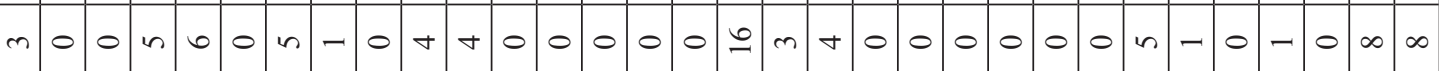

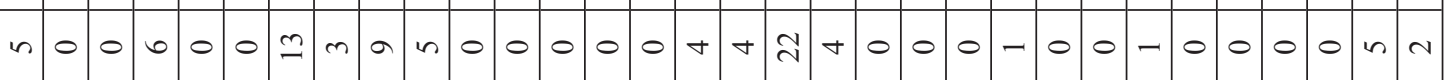

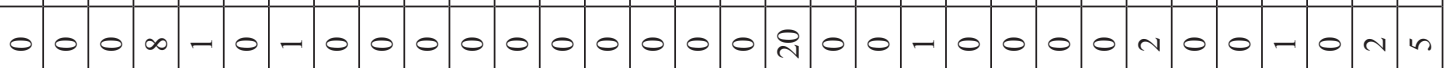

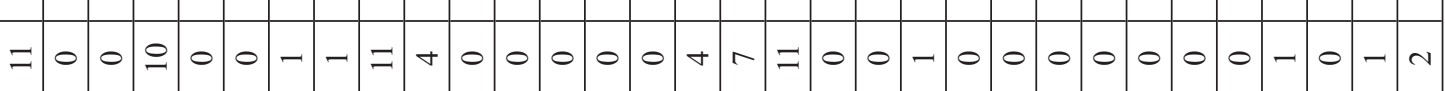

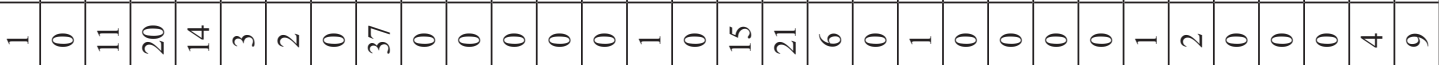

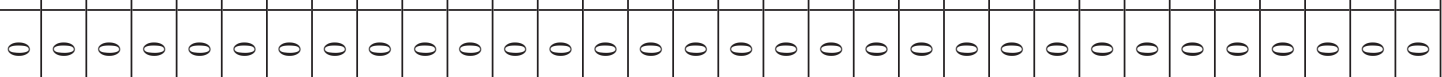

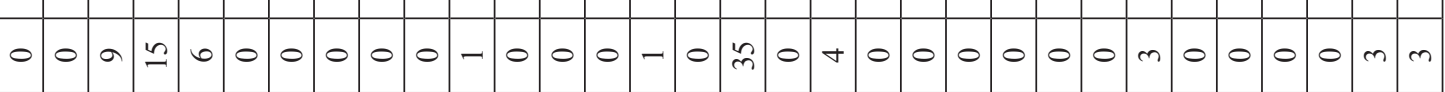

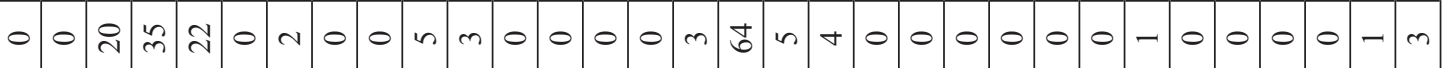
0 o a 0 v

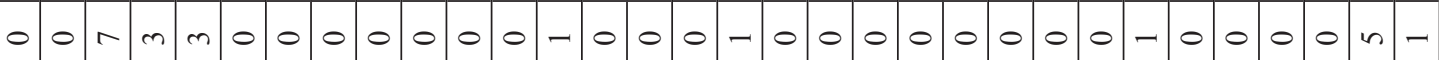

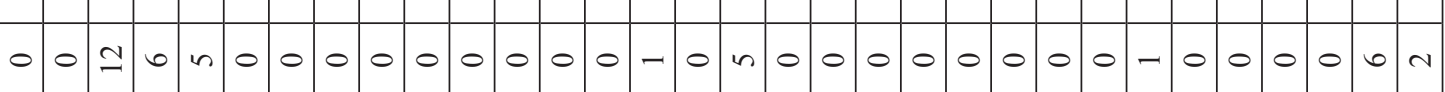
- 0 0 o

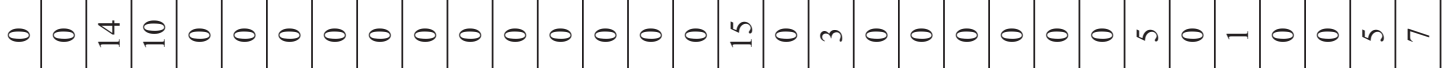

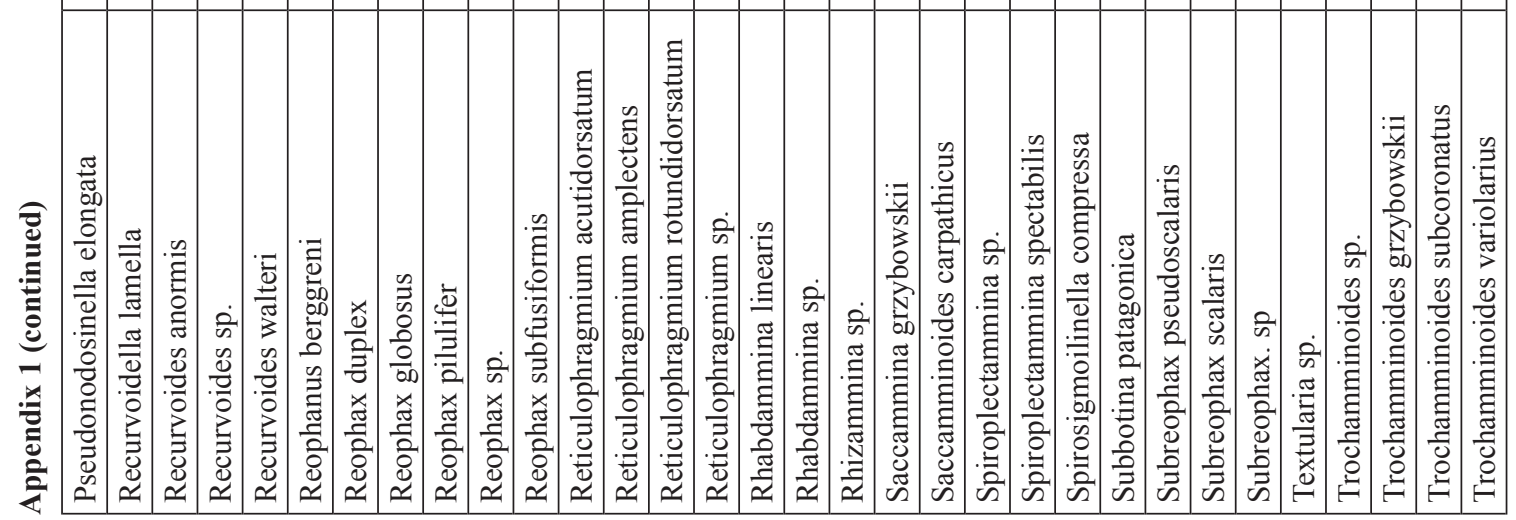

